\title{
Tables as protocol for mass tests input in the Latin and other languages teacher's personal information system interface: integrated technology for Word, Excel, Quizlet, Gift and Moodle
}

\author{
P.G. Matukhin', E.A. Provotorova ${ }^{1}$, O.A. Gracheva ${ }^{1}$, \\ N.V. Komissarova ${ }^{2}$, I.V. Rybakova ${ }^{1}$ \\ ${ }^{1}$ Peoples' Friendship University of Russia (RUDN University) \\ 6 Miklukho-Maklaya St., Moscow, 117198, Russian Federation \\ ${ }^{2}$ Moscow Metropolitan Governance University \\ 99 Ryazansky prospect, Moscow, 109542, Russian Federation
}

\begin{abstract}
Under investigation is the combined use of the LMS MOODLE and special language teaching tools like QUIZLET. The core is the task of unification of the mass tests format and their import into LMS. The initial form of test arrays are WORD lists or EXCEL spreadsheets. The table structure of the AIST interface is proposed. The automated process of arrays converting from WORD and EXCEL tables to GIFT files for import into the MOODLE and QUIZLET is described. Shown that the use of the tabular interface makes anyone possible to implement an effective technology of mass test import into various language LMS.
\end{abstract}

Key words: Information technologies, distant and blended education, input data unification, mass testing, mobiles, tables, training control

On preparatory departments and initial courses of the university students study ancient and modern languages. It is Latin for medical and legal fields. Students in many other fields study English. Foreign citizens learn Russian as a foreign language (RFL). Language training often occurs in an accelerated mode. To improve the quality of the educational process teachers should develop and use special manuals, modern information tools and technologies.

The market of information products and mobile applications for educational purposes is raising from day-to-day. This paper presents some results of a study of the possibilities of joint application of different programs - corporate LMS MOODLE and QUIZLET, a special program of language training. A unified Protocol of input data preparation for training sets and test tuples is proposed. The tabular structure allows anyone to create a comprehensive test load technology for both environments.

Problem. Teachers of Latin and other languages faced the problem. A new organization of educational communication is required [1;2]. It should be based on the joint use of mobile devices and ready-made online tools.

Documents, tables, presentations can be easily placed into online archives [3; 4]. There is also a plenty of different tools for the educational feedback [5]. Each program 
requires a specific format of the source data. Teacher meets limitations in the combined use of special tools in the complex author information system of language training (AIST).

The up-to-date standard of corporate online systems is the MOODLE LMS. The developers have provided good opportunities to organize and control the individual work of the student [6]. However, this system does not provide special training tools for exercises. An important element of the method is the possibility of using a wide range of group training techniques. The MOODLE cannot provide group exercises. Therefore, the language teacher faces the problem to enlarge his/her arsenal of language training mobile application. A combination of mass approach to transformation of components and simultaneous flexibility of technology required. Note, we do not proclaim the purpose of full automation. But a combination of automatic and manual operations.

In our study, we intended to focus on the preparation of the initial training content. We started to create a simple technology that allows anyone to transform pre-prepared question sets [7] into files suitable for uploading to the all components of the AIST.

Thus, we expect to achieve the main goal - to develop a model of information technology for the preparation and unification of arrays of test tasks, which are intended for import in the QUIZLET MODULE. As well as for subsequent input into the MOODLE BANK of questions. The core of the new technology should be a data exchange Protocol. Its function is to provide an appropriate interface between the components of the AIST. We suppose the WORD lists, WORD table, and EXCEL spreadsheet to be the initial form of the raw test arrays.

Method. Special training kits used general-purpose computer programs: WORD, EXCEL have been developed [5; 7]. The next was the use of mobiles and BYOD (Bring Your Own Device) technology [8; 9]. Good results were obtained with the HOT POTATOES [10].

Using for the distant and blended learning the OneDrive/Excel-online cloud version built-in functions a plenty of different Latin, Russian as a Foreign Language, English test sets for classroom and self-study were prepared [7]. These tables are relevant for today use. They can be used as complementary components of corporate and specialized learning environments, such as MOODLE or QUIZLET. We need to develop the improved technology in terms of these arrays into new systems input.

The fundament of the development are the classical principles of the educational information systems construction [12].

Usually tests are made within the question BANK via manual input. The set of import formats includes GIFT, MOODLE XML, Aiken, Blackboard, WebCT, Examview, Microsoft Word 2010 table format, Embedded answers (Cloze), and Missing word. Special software is required. The only appropriate format for our purposes is a special markup language for text files GIFT - General Import Format Template. We chose it because to prepare a set of test questions teacher needs only arrange items as a WORD or EXCEL table.

Note, in this study we consider only one type of test questions - quizzes. Those implies to choose one correct answer from the list of options.

The operation assumes an insert of special markup characters into the questions table. This is a fundamental feature in the process of preparation of mass tests, which can include up to hundreds of questions. 


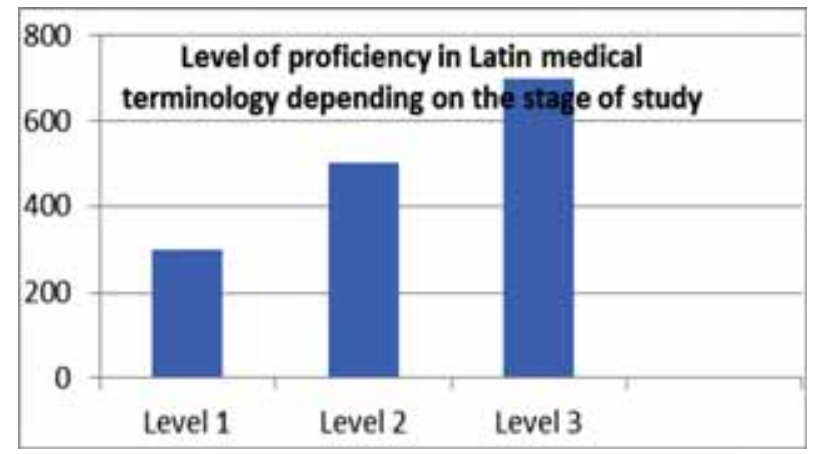

Figure. Lexical minimum for levels 1, 2, 3 of the Latin as the LSP

The entire volume of vocabulary in Latin as a Language for Specific Purposes for medical students divided into 3 subsections - anatomical, clinical and pharmaceutical terminology (Figure). The system should enable students to learn the necessary volume of vocabulary in the independent mode.

With a standard approach, systems requires a teacher to prepare a special import array. The most adjustable solution to the problem of the data form seems to be the table.

The results presented below we obtained in the course of implementation of joint interdisciplinary projects of teachers of language and computer disciplines.

Results. The model of the AIST includes the corporate LMS and custom applications. The base of it is the principle of universality of the data form. This form acts as a common interface between all the components of the AIST. It is an analogue of the data exchange Protocol in computer systems. Earlier we used tables to support educational communication via the OneDrive cloud storage. The advantage is the fact that it guarantees the safety of the information entered, protects against accidental errors.

We ranged a certain sequence of the test question elements (tuple). The scheme contains the title of the question, its wording, the correct answer, a set of incorrect answers. The question title role performs numbering. The wording of the questions is standardized. Correct answers teacher should place in the first position of the answers sub tuple. The order of incorrect answers can be arbitrary because the test designer enables randomization.

This tabular scheme is the AIST interface Protocol. It serves as the media for a complex technology of data input for all components of the system. The Protocol allows importing question tuples into the QUIZLET without any additional transformations. The teacher needs only to organize the correct order of the exercises in the classroom and to give students recommendations for the out-of-classes self-training.

To import a question set in the MOODLE BANK, anyone needs to create a GIFT file. The test header should be limited from two sides by a pair of colons "::". Then enclose in curly braces " $\{\ldots . . .$.$\} " the answers. Mark the first correct answer by the "=" sign, and$ incorrect answers by inserting the sign " " before them. After special characters placing, merge the text rows of the EXCEL table cells using the CONCATENATE() function. The concatenation result is then supplemented with empty strings and copied into a text file. Thereafter, the resulting GIFT format file anyone can enter in MOODLE, using the IMPORT command from a BANK of QUESTIONS set. After that, a new test can be designed. 
Discussion. Originally, the technology was tested by language teachers at the pregraduate faculty for tuition of foreign students of engineering directions in RFL. Legal fundamentals of the RFL teaching and certification clearly stated by a number of decrees [13].

The development is also used to prepare exercises and test tasks in the Latin language for students of humanitarian and medical areas. At the faculty of Philology acquaintance with the Latin, language is clearly structured, depending on the direction of the course it takes 2 or 3 semesters. The introduction of the early studied vocabulary in the following modules allows students to repeat the terms and to feel the inner connections and the integrity of the language. This way shows how the technique allows the teacher to implement the principle of succession in the language teaching and learning.

Due to the limited scope of this work, we did not touch the output of test results and the preparation of reports. We plan to present them in a separate paper.

Using a tabular interface with a standard configuration of questions tuples, anyone can implement a practical and effective technology to import tests into different language learning environments. At the same time, the tabular Protocol guarantees the security of the language learning content.

The paper seems to be interesting for language teachers and humanities teachers refresh courses professors and attendee.

(C) Matukhin P.G., Provotorova E.A., Gracheva O.A., Komissarova N.V., Rybakova I.V., 2018

This work is licensed under a Creative Commons Attribution 4.0 International License

\section{References}

[1] Gracheva O.A., Matukhin P.G., Elsgolts S.L. Mezhpredmetnye informacionno-tekhnologicheskie proekty v razrabotke uchebno-metodicheskih posobij po russkomu yazyku dlya fizikov [Intersubject IT projects: Development of manuals on the Russian language for physicists]. Vestnik Rossijskogo universiteta druzhby narodov. Seriya: Informatizaciya obrazovaniya [Bulletin of Peoples' Friendship University of Russia. Informatization in Education series]. 2013. No. 4. Pp. 27-39.

[2] Komissarova N.V. Teaching English via IT Tools and Professional Communication. Materialy XXI Mezhdunarodnoj konferencii Nacional'nogo ob"edineniya prepodavatelej anglijskogo yazyka $v$ Rossii [ Proceedings of the 21st International Conference of National Association of Teachers of English in Russia]. Yekaterinburg: UGPU, 2015. Pp. 130-131.

[3] Matukhin P.G., Elsgolts S.L., Pevnitskaya E.V., Gracheva O.A., Provotorova E.A. Multimedia Tutorial in Physics for Foreign Students of the Engineering Faculty Preparatory Department. Mechanics, Materials Science \& Engineering. 2016. Vol. 2. Pp. 84-90.

[4] Antokhina E.V., Godina E.Z., Matukhin P.G., Provotorova E.A., Titova E.P. Onlajn-sredstva informacionno-metodicheskoj podderzhki distantnogo izucheniya kursa "Anatomiya cheloveka" dlya inostrannyh studentov predvuzovskogo ehtapa obucheniya na baze oblachnyh BYODtekhnologij Microsoft OneDrive/Word Online [Online tools, information and methodical support of distant learning course "Human Anatomy" for foreign students of pre-university training stage cloud-based BYOD technologies Microsoft OneDrive/Word Online]. Vestnik CMO MGU(IRYAiK) [Bulletin of CMO MGU (IRYAiK)]. 2015. No. 4. Pp. 33-39.

[5] Matyash G.A., Matukhin P.G., Anikina E.O., Provotorova E.A. Sozdanie testov v srede Microsoft Office Excel. Baza voprosov, trenazhery, generator voprosov, testy [Creating tests in Microsoft Office Excel. Base questions, simulators, question generator, tests]. Moscow: RAO, 2013. Pp. 1-35. 
[6] Gracheva O.A., Matukhin P.G. Innovacionnye ehlementy v obuchenii inostrannyh slushatelej bazovomu yazyku fiziki na osnove oblachnogo resursa OneDrive i SDO Moodle v mobil'nom rezhime [Innovative elements in teaching foreign students the basic language of physics based on the cloud resource OneDrive and SDO Moodle in mobile mode]. Vserossijskaya nauchnoprakticheskaya konferenciya "Aktual'nye voprosy realizacii obrazovatel'nyh programm na podgotovitel'nyh fakul'tetah dlya inostrannyh grazhdan" [Proceedings of All-Russian Scientific and Practical Conference "Topical issues of implementation of educational programs at preparatory faculties for foreign citizens”]. Dnepropetrovsk, 2016. Pp. 410-418.

[7] Gracheva O.A., Matukhin P.G. Innovative elements in foreign students basic language of physics teaching based on cloud resource OneDrive and Moodle distant learning system in mobile mode. All-Russian Scientific-Practical Conference "Topical issues of implementation of educational programs at the preparatory faculties for foreign citizens". Moscow: GIRYAP, 2016. Pp. 123-129.

[8] Gracheva O.A., Elsgolts S.L., Matukhin P.G., Pevnitskaya E.V., Matyash G.A. The base of questions, simulators, test generator and a set of options on Russian as a foreign language for foreign students-physicists. URL: http://www.ofernio.ru/rto_files_ofernio/19358.doc

[9] Elsgolts S.L., Provotorova E.A., Matukhin P.G., Gracheva O.A., Pevnitskaya E.V. Perspektivy ispol'zovaniya BYOD-tekhnologij v WIKI-proektah dlya obrazovatel'noj yazykovoj, predmetnoj i IT-adaptacii inostrannyh studentov [Prospects of using BYOD-technologies in WIKI-projects for educational language, subject and it adaptation of foreign students]. Prepodavanie obshcheobrazovatel'nyh predmetov na russkom yazyke v inoyazychnoj auditorii [Teaching General subjects in Russian in a foreign language classroom]: materialy Mezhdunarodnogo nauchnoprakticheskogo seminara. M.: MOC MG, 2014. Pp. 148-155.

[10] Komissarova N.V., Gleason K., Matukhin P.G. Knowledge Hub: spiral matrix thinking as a communication technology for individual and group learning in OneDrive and Word Online. Vestnik Rossijskogo universiteta druzhby narodov. Seriya: Informatizaciya obrazovaniya [RUDN Journal of Informatization in Education]. 2017. Vol. 14. No. 2. Pp. 194-204.

[11] Komissarova N.V., Gleason K., Matukhin P.G. Spiral'nye trassy v matrice Knowledge Hub kak kommunikativnaya tekhnologiya dlya individual'nogo i gruppovogo obucheniya v srede OneDrive/ Word Online [Spiral tracks in the matrix of the Knowledge Hub as a communication technology for individual and group learning in an environment of OneDrive/Word Online]. Vestnik Rossijskogo universiteta druzhby narodov. Seriya: Informatizaciya obrazovaniya [RUDN Journal of Informatization in Education]. 2017. Vol. 14. No. 2. Pp. 194-204.

[12] Bashmakov A.I., Bashmakov I.A. Razrabotka komp'yuternyh uchebnikov i obuchayushchih sistem [Development of computer textbooks and training systems]. Moscow: Filin, 2003. 616 p.

[13] Matukhin P.G., Grachova O.A., Elsgolts S.L., Pevnitskaya E.V. Tabular organization of the educational content as the basis of the complex BYOD support and monitoring of foreign students studying physics and Russian language, physics-based cloud resource MS OneDrive. Proceedings of International scientific-practical conference "Informatization of Engineering Education". M.: MEHI, 2016. Pp. 681-684.

[14] Komissarova N.V. et al. The Set of Teaching Materials for TRFL Certification Preparation. Part 9. Legal Fundamentals of RFL Teaching and Testing of Foreign Citizens in Russian Centers of Science and Culture Abroad. Chronicles of the United Fund of Electronic Resources "Science and education”. 2017. No. 9. P. 100.

\section{Article history:}

Received: 25 June 2018

Accepted: 30 July 2018

\section{For citation:}

Matukhin P.G., Provotorova E.A., Gracheva O.A., Komissarova N.V., Rybakova I.V. (2018). Tables as protocol for mass tests input in the Latin and other languages teacher's personal information system interface: integrated technology for Word, Excel, Quizlet, Gift and Moodle. 
RUDN Journal of Informatization in Education, 15(4), 424-431. DOI 10.22363/2312-8631-201815-4-424-431

\title{
Bio Note:
}

Matukhin Pavel Granitovich, senior lecturer of the department of computer technologies of the philological faculty of the Peoples' Friendship University of Russia. Contact information: e-mail: m-pg@mail.ru

Provotorova Elena Arkadievna, senior lecturer of the department of foreign languages of the philological faculty of the Peoples' Friendship University of Russia. Contact information: e-mail: provelar@yandex.ru

Gracheva Olga Alekseeva, associate professor of the department of Russian language of the faculty of Russian language and general subjects of the Peoples' Friendship University of Russia. Contact information: e-mail: oagra@hotmail.ru

Komissarova Natalia Valerievna, associate professor of the department of jurisprudence of Moscow Metropolitan Governance University. Contact information: e-mail: natalie_komis@mail.ru

Rybakova Irina Victorovna, senior lecturer of the department of foreign languages of the philological faculty of the Peoples' Friendship University of Russia. Contact information: e-mail: rybakova irina@mail.ru

\section{Таблицы как протокол интерфейса ввода массовых тестов по латинскому и другим языкам в персональной информационной системе преподавателя: комплексная технология для Word, Excel, Quizlet, Gift и Moodle}

\author{
П.Г. Матухин ${ }^{1}$, Е.А. Провоторова ${ }^{1}$, О.А. Грачева ${ }^{1}$, \\ Н.В. Комиссарова ${ }^{2}$, И.В. Рыбакова ${ }^{1}$ \\ ${ }^{1}$ Российский университет дружбы народов \\ Российская Федерация, 117198, Москва, ул. Миклухо-Маклая, 6 \\ ${ }^{2}$ Московский городской университет управления Правительства Москвы \\ Российская Федерация, 109542, Москва, Рязанский проспект, 99
}

В статье представлены результаты проекта по созданию и внедрению в процесс обучения языковым дисциплинам (латинский и английский языки, РКИ) авторской информационной системы (АИС). Выявлены проблемы комбинированного применения СДО Moodle и специальных средств обучения языкам типа Quizlet. Поставлен вопрос унификации формата массовых тестов и их импорта в обучающие среды. Исходной формой организации массивов тестового материала являются списки Word или таблицы Excel. Предложена структура таблицы как формы интерфейса АИС преподавателя. Описан автоматизированный процесс преобразования массивов из таблиц Word и Excel в Gift с целью импорта в Moodle и Quizleт. Показано, что использование табличного интерфейса позволяет реализовать эффективную комбинированную технологию импорта массовых тестовых заданий в различные среды обучения языковым дисциплинам.

Ключевые слова: дистанционное и смешанное образование, обучение языкам, контроль обучения, массовое тестирование, мобильные приложения, интерфейс, таблицы 


\section{Список литературы}

[1] Грачёва О.А., Матухин П.Г., Эльсгольи С.Л. Межпредметные информационно-технологические проекты в разработке учебно-методических пособий по русскому языку для физиков // Вестник Российского университета дружбы народов. Серия: Информатизация образования. 2013. № 4. С. 27-38.

[2] Komissarova N.V. Teaching English via IT Tools and Professional Communication // Материалы XXI Международной конференции Национального объединения преподавателей английского языка в России. Екатеринбург: УГПУ, 2015. С. 130-131.

[3] Matukhin P.G., Elsgolts S.L., Pevnitskaya E.V., Gracheva O.A., Provotorova E.A. Multimedia Tutorial In Physics for Foreign Students of the Engineering Faculty Preparatory Department // Mechanics, Materials Science \& Engineering. 2016. Vol. 2. Pp. 84-90.

[4] Антохина Е.В., Година Е.З., Матухин П.Г., Провоторова Е.А., Титова Е.П. Онлайн-средства информационно-методической поддержки дистантного изучения курса «Анатомия человека» для иностранных студентов предвузовского этапа обучения на базе облачных BYOD-технологий Microsoft OneDrive/Word Online // Вестник ЦМО МГУ. 2015. № 4. C. $33-39$.

[5] Матяш Г.А., Матухин П.Г., Аникина Е.О., Провоторова Е.А. Создание тестов в среде Microsoft Office Excel. База вопросов, тренажеры, генератор вопросов, тесты. М.: РАО, 2013. C. $1-35$.

[6] Грачёва О.А., Матухин П.Г. Инновационные элементы в обучении иностранных слушателей базовому языку физики на основе облачного ресурса OneDrive и СДО Moodle в мобильном режиме // Всероссийская научно-практическая конференция «Актуальные вопросы реализации образовательных программ на подготовительных факультетах для иностранных граждан». Днепропетровск, 2016. С. 410-418.

[7] Gracheva O.A., Matukhin P.G. Innovative elements in foreign students basic language of physics teaching based on cloud resource OneDrive and Moodle distant learning system in mobile mode // All-Russian scientific-practical conference "Topical issues of implementation of educational programs at the preparatory faculties for foreign citizens". М.: ГИРЯП, 2016. С. 123-129.

[8] Gracheva O.A., Elsgolts S.L., Matukhin P.G., Pevnitskaya E.V., Matyash G.A. The base of questions, simulators, test generator and a set of options on Russian as a foreign language for foreign studentsphysicists. URL: http://www.ofernio.ru/rto_files_ofernio/19358.doc

[9] Эльсгольи С.Л., Провоторова Е.А., Матухин П.Г., Грачева О.А., Певницкая Е.В. Перспективы использования BYOD-технологий в WIKI-проектах для образовательной языковой, предметной и ИТ-адаптации иностранных студентов // Преподавание общеобразовательных предметов на русском языке в иноязычной аудитории: материалы Международного научно-практического семинара. М.: МОЦ МГ, 2014. С. 148-155.

[10] Komissarova N.V., Gleason K., Matukhin P.G. Knowledge Hub: spiral matrix thinking as a communication technology for individual and group learning in OneDrive and Word Online // Вестник Российского университета дружбы народов. Серия: Информатизация образования. 2017. Т. 14. № 2. С. 194-204.

[11] Комиссарова Н.В., Глисон К., Матухин П.Г. Спиральные трассы в матрице Knowledge Hub как коммуникативная технология для индивидуального и группового обучения в среде OneDrive/Word Online // Вестник Российского университета дружбы народов. Серия: Информатизация образования. 2017. Т. 14. № 2. С. 194-204.

[12] Башмаков А.И., Башмаков И.А. Разработка компьютерных учебников и обучающих систем. М.: Филин, 2003. 616 с.

[13] Matukhin P.G., Grachova O.A., Elsgolts S.L., Pevnitskaya E.V. Tabular organization of the educational content as the basis of the complex BYOD support and monitoring of foreign students studying physics and Russian language, physics-based cloud resource MS OneDrive // Proceedings of International scientific-practical conference "Informatization of Engineering Education". M.: MEI, 2016. Pp. 681-684. 
[14] Komissarova N.V. et al. The Set of Teaching Materials for TRFL Certification Preparation. Part 9. Legal Fundamentals of RFL Teaching and Testing of Foreign Citizens in Russian Centers of Science and Culture Abroad // Chronicles of the United Fund of Electronic Resources "Science and education". 2017. No. 9. P. 100.

\section{История статьи:}

Дата поступления в редакцию: 25 июня 2018

Дата принятия к печати: 30 июля 2018

\section{Для цитирования:}

Matukhin P.G., Provotorova E.A., Gracheva O.A., Komissarova N.V., Rybakova I.V. Tables as protocol for mass tests input in the Latin and other languages teacher's personal information system interface: integrated technology for Word, Excel, Quizlet, Gift and Moodle (Таблицы как протокол интерфейса ввода массовых тестов по латинскому и другим языкам в персональной информационной системе преподавателя: комплексная технология для Word, Excel, Quizlet, Gift и Moodle) // Вестник Российского университета дружбы народов. Cерия: Информатизация образования. 2018. Т. 15. № 4. С. 424-431. DOI 10.22363/2312-86312018-15-4-424-431

\section{Сведения об авторах:}

Матухин Павел Гранитович, старший преподаватель кафедры компьютерных технологий филологического факультета Российского университета дружбы народов. Контактная информация: e-mail: m-pg@mail.ru

Провоторова Елена Аркадьевна, старший преподаватель кафедры иностранных языков филологического факультета Российского университета дружбы народов. Контактная информация: e-mail: provelar@yandex.ru

Грачева Ольга Алексеевна, доцент кафедры русского языка факультета русского языка и общеобразовательных дисциплин Российского университета дружбы народов. Контактная информация: e-mail: oagra@hotmail.ru

Комиссарова Наталья Валерьевна, доцент кафедры юриспруденции Московского городского университета управления Правительства Москвы. Контактная информация: e-mail: natalie_komis@mail.ru

Рыбакова Ирина Викторовна, старший преподаватель кафедры иностранных языков филологического факультета Российского университета дружбы народов. Контактная информация: e-mail: rybakova_irina@mail.ru 